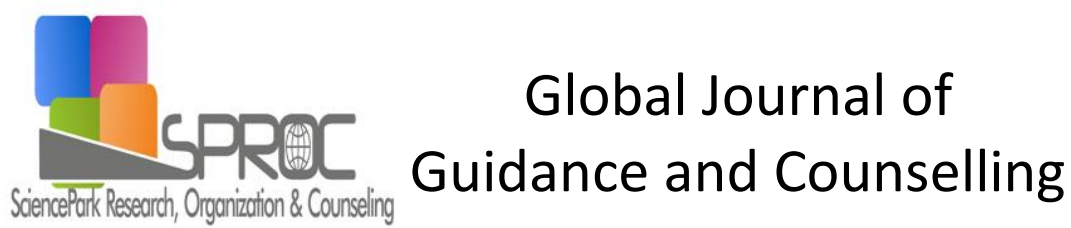

Volume 05, Issue 2, (2015) 67-71

http://sproc.org/ojs/index.php/gigc

\title{
Emotional intellengence in university students
}

\author{
Mualla Yilmaz *, School Health Sciences, Psychiatric Nursing Department, Mersin University, Mersin, \\ Turkey. \\ Meral Altiok, Health High School, Internal Medicine, Nursing ABD, Mersin University Mersin, Turkey. \\ Zeliha Yaman, Health High School, Internal Medicine, Nursing ABD, Mersin University Mersin, Turkey. \\ Sevgi Seyrek, Ozel Mersin Merkez Anadolu Saglik Meslek Lisesi, Mersin, Turkey. \\ Yagmur Surmeli, Karaman Devlet Hospital, Konya, Turkey. \\ Mehmet Ali Sungur, Faculty of Medicine, Biostatistics and Medical Informatics USA, Duzce University, \\ Duzce, Turkey.
}

\section{Suggested Citation:}

Yilmaz, M., Altiok, M., Yaman, Z., Seyrek, S., Surmeli, Y., \& Sungur, M., A. (2015). Emotional intellengence in university students. $\quad d \quad d \quad m d f d \quad$ t $m$. (2), 67-71.

Received 30 September, 2015; revised 24 October, 2015; accepted 07 November, 2015.

Selection and peer review under responsibility of Prof. Dr. Kobus Maree, South Africa.

${ }^{\circ} 2016$ SciencePark Research, Organization \& Counseling. All rights reserved.

\begin{abstract}
This study was conducted to determine the status of university students' emotional intelligence. The sample of this descriptive research is composed of students who have stuidied at a four year university. They are selected according to criteria of faculty and gender based on the random sampling. The data was collected using "Personal Information Form", Bar-On Emotional Intellegent Inventory. Mean, standard deviation, Independent Samples t-test, one way ANOVA tests were used for the evaluation. This study, female university students' emotional intelligence total scale and all of subscale of the mean scores were determined to be higher than male students. The emotional intellegence of the university students who are training in physical sciences was determined to be higher than that of students studying in other sections. The emotional intellegence of the university students who are training in the first class was determined to be higher than the students studying in other classes. Results: In this study, female university students' emotional intelligence total scale and all of subscale of the mean scores were determined to be higher than male students. The emotional intellegence of the university students who are training in physical sciences was determined to be higher than that of students studying in other sections. The emotional intellegence of the university students who are training in the first class was determined to be higher than the students studying in other classes.
\end{abstract}

Keywords: University, student, emotional intelligence

*ADDRESS FOR CORRESPONDENCE: Mualla Yilmaz, School Health Sciences, Psychiatric Nursing Department, Mersin University, Mersin, Turkey. $\quad d m d \quad$ ttr: mualley69@gmail.com 
Yilmaz, M., Altiok, M., Yaman, Z., Seyrek, S., Surmeli, Y., \& Sungur, M., A. (2015). Emotional intellengence in university students. $d \quad d \quad m d f d$ th $m$. (2), 67-71.

\section{Introduction}

Emotional intelligence involves the ability to be aware of emotions, to cope with emotions, to motivate oneself, to build empathy, and to manage interpersonal relations (Avsar and Kasıkc 2010; Reeves 2005; Salovey and Mayer 1990). Emotional intelligence is extremely important in the private and professional lives of individuals (Avsar \& Kasıkcı 2010). Goleman identifies five components of emotional intelligence: self-awareness, self-regulation, internal motivation, empathy and social skills (Goleman, 2001). These skills and competences are critical for the success of individuals of all ages and professions, particularly for the success of those individuals in professions serving people. What is meant by the word success is not only status, career or wealth. Feeling content, establish good relationships with others, and taking pleasure in life are also factors determining success (Unsar et al. 2009; Acar 2002).

"Self-awareness", a component of emotional intelligence, is an important determinant of students' academic achievement (Yazıcı et al. 2011). The ability to work with others, to be tolerant, to respect differences and to solve conflicts with a constructive manner is extremely important for being healthy, strong and successful (Pala 2008).

It is essential to develop students' emotional intelligence during their university education (Brannick 2009, Stuart 2004). The professionals of the future need emotional intelligence to recognize their own feelings; to perceive, understand and manage the feelings of others; to employ these skills in order to guide their behaviour; and to be happy and successful.

The primary objective of this research was to examine the emotional intelligence status of university students as professionals of the future. Also, the study aimed to determine whether university students' levels of emotional intelligence differed according to gender and majors.

\section{Method}

This descriptive study was conducted with undergraduate students at Mersin University.

The study population consisted of a total of 10560 students (5236 female and 5324 male students) who were doing their undergraduate degrees during 2011-2012 academic year. The sample, on the other hand, was selected by stratified random sampling method based on major of study and gender. The minimum sample size to predict the population efficiently was estimated to be $10 \%$ of the population (Blanche 2006). In this sense, the minimum sample of 523 girls and 1055 constitute the survey, including 532 male students. In light of this, the study sample consisted a minimum of 1055 students ( 523 female and 532 male students).

\section{Measures}

Data were collected using the Personal Information Form developed by the researchers and the Bar-On Emotional Quotient Inventory through face-to-face interviews.

The Personal Information Form consisted of 12 questions about the university students' socio-demographic features. The questions addressed the participants' gender, age, place of birth, previous graduation, current place of residence, family structure, major of study, department, marital status and status of having children.

The Bar-On Emotional Quotient Inventory was adapted for Turkish culture by Acar (2002). The Bar-On Emotional Quotient Inventory is a Likert-type scale consisting of 87 items (Acar 2002).

The study was conducted with those students who volunteered to participate in the study after the ethics committee and the institution approved the study, the participants were informed about the purpose and methodology of the study, and their written and verbal consents were received. 
Yilmaz, M., Altiok, M., Yaman, Z., Seyrek, S., Surmeli, Y., \& Sungur, M., A. (2015). Emotional intellengence in university students. $d \quad d \quad m d f d$ t $\quad m$. (2), 67-71.

\section{Statistical analyses}

Statistical analyses were performed using MedCalc. The analyses included mean \pm standard deviation, independent samples t-test and One Way ANOVA, and results were considered significant if $p<0.05$.

\section{Results}

Table 1. Emotional Intellengence with Socio-Demographic Characteristics of Unıversıty Students Bar-On Duygusal Zeka Olcegi

\begin{tabular}{|c|c|c|c|c|c|c|c|}
\hline Character & & $\begin{array}{l}\text { Kisisel } \\
\text { Beceriler }\end{array}$ & $\begin{array}{l}\text { Kisilerarası } \\
\text { Beceriler }\end{array}$ & $\begin{array}{l}\text { Uyumluluk } \\
\text { Boyutu }\end{array}$ & $\begin{array}{l}\text { Stresle } \\
\text { Basa } \\
\text { Cıkma } \\
\text { Boyutu }\end{array}$ & $\begin{array}{l}\text { Genel } \\
\text { Ruh } \\
\text { Durumu } \\
\text { Boyutu }\end{array}$ & $\begin{array}{l}\text { Toplam } \\
\text { Olcek }\end{array}$ \\
\hline \multicolumn{8}{|l|}{ Gender } \\
\hline Female & $524(49.48)$ & $3.53 \pm 0.50$ & $3.66 \pm 0.54$ & $3.44 \pm 0.44$ & $3.10 \pm 0.47$ & $3.58 \pm 0.56$ & $3.50 \pm 0.41$ \\
\hline Male & $535(50.51$ & $3.48 \pm 0.49$ & $3.51 \pm 0.52$ & $3.41 \pm 0.46$ & $3.15 \pm 0.49$ & $3.50 \pm 0.57$ & $3.43 \pm 0.40$ \\
\hline & & 0.085 & 0.001 & 0.217 & 0.058 & 0.021 & 0.020 \\
\hline \multicolumn{8}{|c|}{ Place of birth } \\
\hline County & $553(52.22)$ & $3,53 \pm 0.50$ & $3.61 \pm 0.53$ & $3.43 \pm 0.45$ & $3.12 \pm 0.46$ & $3.55 \pm 0.56$ & $3.47 \pm 0.40$ \\
\hline Town & $362(34.18)$ & $3,51 \pm 0.51$ & $3.58 \pm 0.56$ & $3.45 \pm 0.45$ & $3.16 \pm 0.51$ & $3.54 \pm 0.61$ & $3.47 \pm 0.43$ \\
\hline Bay & $144(13.60)$ & $3,44 \pm 0.48$ & $3.54 \pm 0.50$ & $3.41 \pm 0.48$ & $3.13 \pm 0.52$ & $3.49 \pm 0.53$ & $3.41 \pm 0.40$ \\
\hline p & & 0.175 & 0.363 & 0.672 & 0.468 & 0.471 & 0.342 \\
\hline \multicolumn{8}{|c|}{ Marital Status } \\
\hline Married & $9(0.85)$ & $3.35 \pm 0.61$ & $3.18 \pm 0.54$ & $3.15 \pm 0.60$ & $3.13 \pm 0.66$ & $3.37 \pm 0.60$ & $3.25 \pm 0.47$ \\
\hline Single & $\begin{array}{l}\text { 1050(99.1 } \\
5)\end{array}$ & $3.51 \pm 0.49$ & $3.59 \pm 0.53$ & $3.43 \pm 0.45$ & $3.13 \pm 0.48$ & $3.54 \pm 0.57$ & $3.46 \pm 0.41$ \\
\hline \multicolumn{8}{|l|}{ p } \\
\hline \multicolumn{8}{|c|}{ Family Structure } \\
\hline $\begin{array}{l}\text { Nucleusfa } \\
\text { mily }\end{array}$ & $878(82.91)$ & $3.52 \pm 0.50$ & $3.59 \pm 0.54$ & $3.44 \pm 0.44$ & $3.12 \pm 0.48$ & $3.54 \pm 0.57$ & $3.46 \pm 0.40$ \\
\hline $\begin{array}{l}\text { Extended } \\
\text { family }\end{array}$ & $154(14.54)$ & $3.42 \pm 0.49$ & $3.58 \pm 0.51$ & $3.38 \pm 0.47$ & $3.19 \pm 0.53$ & $3.53 \pm 0.54$ & $3.43 \pm 0.41$ \\
\hline Others & $27(2.55)$ & $3.56 \pm 0.59$ & $3.53 \pm 0.70$ & $3.42 \pm 0.62$ & $3.13 \pm 0.55$ & $3.53 \pm 0.72$ & $3.46 \pm 0.50$ \\
\hline p & & 0.061 & 0.771 & 0.275 & 0.239 & 0.952 & 0.546 \\
\hline
\end{tabular}

\section{Discussion}

The average scores of the female participants for the emotional quotient scale and its subscales were higher than those of the male participants. One of the factors affecting emotional intelligence is gender. Research suggested that women tend to have higher levels of emotional intelligence than men (Gurbuz et al. 2008; Koksal et al. 2007; Petrides 2000, Karaka, et al. 2011). However, some studies identified no significant relationship between gender and emotional intelligence (Birol et al. 2009; Babaoglu 2010; Janissaries et al. 2014; Erdem et al. 2013).

We found that the participants who were living in a nuclear family, who were single and who were living in a city centre had higher levels of emotional intelligence.

Our single participants' higher scores of emotional intelligence than the married ones could be due to the fact that the freedom enjoyed by single students allowed them to take 
Yilmaz, M., Altiok, M., Yaman, Z., Seyrek, S., Surmeli, Y., \& Sungur, M., A. (2015). Emotional intellengence in university students. $d \quad d \quad m d f d$ th $m$. (2), 67-71.

responsibility and to devote more time to other individuals with problems and, therefore, to develop their emotional intelligence by using it in dealing with a lot more problems.

Also, those participants doing a major of science received higher scores on the emotional quotient total scale and in the subscales than other participants doing different majors. Similarly, Arl et al. found that teacher candidates who were graduates of science received higher scores on the self-regulation subscale than those who were graduates of literature (Arl et al. 2011).

Finally, we found that the participants in their first year of university education received higher scores on the emotional quotient total scale and in the subscales than other participants their second, third or fourth year. In a study by Yilmaz and Ozkan (2011), on the other hand, third year student received the lowest average score of emotional intelligence while fourth year students received the highest average score. Nevertheless, Sevindik et al. (2012) found that first year students had the lowest average score of emotional intelligence while second year students had the highest average score.

To sum up, although it is generally assumed that university education contributes to the development of emotional intelligence among students, our findings showed that university students' level of emotional intelligence tended to decrease through the end of their university education. In light of this, there seems to be a need to revise the curriculum higher education and create educational strategies to improve the emotional intelligence of male students in particular.

\section{References}

Acar, F.T. (2002). Duygusal Zeka ve Liderlik. $\quad t^{m} d \quad \mathrm{~mm} \quad$ tt $m$ th $\quad \mathrm{tm} 12$, 53-68.

Arl, D., Altunay, E., \& Yalcinkaya, M. (2011). Ogretmen Adaylarında Duygusal Zekâ, Problem Cozme ve Akademik Basarı lliskisi. $E d \quad m \quad d \quad t \quad \mathrm{tm}$, 1-23.

Arora, S., Ashrafian, H., Davis, R, Athanasiou T, Darzi A, Sevdalis N. (2010). Emotional Intelligence in Medicine: a Systematic Review Through The Context Of The ACGME Competencies. nfd fd $m \quad 749-764$.

Avsar, G., \& Kasikci, M. (2010). Hemsirelik Yuksekokulu Ogrencilerinde Duygusal Zeka Duzeyi. Anadolu $M \quad t m m^{f} d \mathrm{~m} \mathrm{~mm} \quad m \quad \mathrm{~mm}$ (1), 1-6.

Babaoglan, E. (2010). Okul Yoneticilerinde Duygusal Zeka. E $m^{f} d \quad$ it $t \mathrm{tm} t \mathrm{tm} \quad \mathrm{mm} L d \quad \mathrm{tm} \quad \mathrm{tm}$ (1), 119-136.

Blanche M.T. (2006). $m \quad d m$ th $d f \quad d f$ nf $E m \quad m$ tiL fro $f m f t$ (Second Edition). University of Cape Town Press. 134.

Birol, C., Atamturk, H., Silman, F., \& Sensoy, S. (2009). Analysis of the Emotional intelligenge Level Of Teachers. $f$ id frd $d \quad d^{f} m d \quad f m f t, 2606-2614$.

Brannic, M., T., Wahi, M.M., Arce, M., Jonson, H., A., Nazian, S., \& Goldin SB. (2009). Comparison of Trait and Ability Measures of Emotional intelligence in Medical Students. nfid $f d m, 1062-$ 1068.

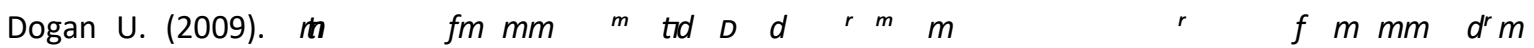
in $\quad f \quad t m d^{m} m d \quad d m$ th $m$ th $t{ }^{r} m$ Mugla Universitesi, Mugla.

Erdem M, ilgan A, Celik F. (2013). Lise Ogretmenlerinin Duygusal Zeka Duzeyleri Ile Elestirel Dusunme Egilimleri Arasındaki iliski. in $m t \quad d m d \quad m$ nff $L \quad d \quad d \quad t \quad m d$ $\begin{array}{lllll}d & \text { Mr } & m & \text { in } & \text { (8), 509-532. }\end{array}$

Gurbuz, S., \& Yuksel, M. (2008). Calisma Ortaminda Duygusal Zeka: Is Performansi, Is Tatmini, Orgutsel Vatandaslik Davranisi ve Bazi Demografik Ozelliklerle lliskisi. th th tm tm $\quad$ trm (2), 174190.

Goleman D. (2001). $\quad{ }^{m}$ tid $^{r} \quad d$ Cev: Yuksel BS. (19. Baskı). İstanbul: Varlık Yayınları.

Karakas SA, Kucukoglu S. (2011). Bir Egitim Hastanesinde Calısan Hemsirelerin Duygusal Zeka Duzeyleri,

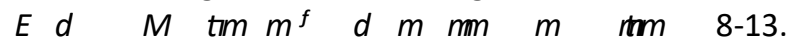


Yilmaz, M., Altiok, M., Yaman, Z., Seyrek, S., Surmeli, Y., \& Sungur, M., A. (2015). Emotional intellengence in university students. $d \quad d \quad m d f d$ to $m$. (2), 67-71.

Korkman, H., \& Deniz, M.E. (2014). Universite Ogrencilerinin Bazı Demografik Degiskenlerinin Yukleme Karmasıklıgı, Duygusal Zeka ve Akıcı Zeka Cercevesinde İncelenmesi. $E d \quad$ m $m \mathrm{~mm}^{f}$

$$
m \quad \text { trm (2), 14-28. }
$$

Korkman H, Deniz ME. (2014). Universite Ogrencilerinin Yukleme Karmasıklıgı Puanlarının Duygusal Zeka ve Akıcı Zeka Cercevesinde İncelenmesi. $E t^{m} d \quad m \quad t r m$ (2), 27-37.

Koksal A, Gazioglu E.ì. (2007). Ergenlerde Duygusal Zeka İle Karar Verme Stratejileri Arasındaki îliski. Mdtid E $m$ f $\quad \mathrm{mm}$ Ld $\mathrm{tm} \quad \mathrm{trm}$ (1), 133-146.

Pala A. (2008). Ogretmen Adaylarının Empati Kurma Duzeyleri Uzerine Bir Arastırma. $d \quad d$ th $\mathrm{tm} \mathrm{tm} \mathrm{mm}$ Ld $\mathrm{tm} \quad \mathrm{trm}$ (1), 13-23.

Petrides, K., V., \& Furnham, A. (2010). Gender Differences In Measured And Self Estimated Trait Emotional İntelligence. $S^{\prime}$ th $(5 / 6), 449-461$.

Reeves A. (2005). Emotional Intelligence Recognizing And Regulating Emotions. EE M $\quad d \quad 53$ (4), 172-176.

Salovey, P., \& Mayer, J., D. (1990). Emotional Intelligence. $d m d m \quad m m \quad d \quad t \quad d m^{m}$ 9(3), 185-211.

Sevindik, F., Uncu, F., \& Gunes, D., D. (2012). Saglık Yuksekokulu Ogrencilerinin Duygusal Zeka Duzeylerinin Bazı Degiskenler Acısından Incelenmesi. $L d d \quad$ th tim tim d $m \quad$ trm (1), 21- 26.

Stuart P. (2004). Emotional Intelligence: Developing Emotionally Literate Training In Mental Health. $d M d \quad d f$ nf , (1), 12-15.

Sen, H., Yılmaz, F., Ozcan, D., \& Bahcecik, N. (2013). Kamu Hastanelerinde Gorev Yapan Bas Hekim ve Bashemsirelerin Duygusal Zeka Duzeyleri İle Etik Muhakeme Yetenekleri ve Etkileyen Faktorler.

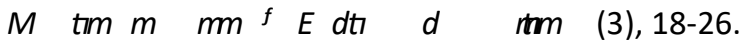

Tambag, H., Kaykunoglu, M., Gunduz, Z., \& Demir, Y. (2014). Hemsirelik Ogrencilerinin Duygusal Zeka Duzeyleri Ve Etkileyen Faktorler. $M \quad t m m \quad m m^{f} E d t \quad d \quad$ trm (1), 41-46.

Unsar, S., Fındık, U.Y., Sadırlı, SK, Erol, O., \& Unsar, S. (2009). Edirne Saglık Yuksekokulu Ogrencilerinin Duygusal Zeka Duzeyleri. it tim ${ }^{f} \quad \mathrm{~mm} \quad \mathrm{~mm}^{f}$ th $f \quad \mathrm{trm}$ (1), 1-13.

Yazici, H., Seyis, S., \& Altun F. (2011). Emotional Intelligence And Self-Efficacy Beliefs As Predictors Of Academic Achievement Among High School Students. $f$ rd frd $d \quad d^{f} m d \quad f m f t$ 2319-2323.

Yeniceri, E., N., Seydaogulları, A., Gulec, S., Yildiz, E., Baldemir, E., \& Caylak, S. (2014). Mugla Sitki Kocman Universitesi Tip Fakultesi Ogrencilerinin Duygusal Zeka Duzeyleri. $\quad d m m f d t$

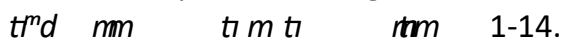

